\title{
Differential pharmacology and clinical utility of rolapitant in chemotherapy-induced nausea and vomiting
}

\section{Bernardo Leon Rapoport \\ The Medical Oncology Centre of Rosebank, Johannesburg, South Africa}

Correspondence: Bernardo Leon Rapoport

The Medical Oncology Centre of Rosebank, 129 Oxford Road, Corner Northwold, Saxonwold, Johannesburg 2196, South Africa

Tel +27 I I 8804169

Email brapoport@rosebankoncology.co.za
This article was published in the following Dove Press journal:

Cancer Management and Research

22 February 2017

Number of times this article has been viewed

\begin{abstract}
Chemotherapy-induced nausea and vomiting (CINV) is a debilitating side effect of many cytotoxic chemotherapy regimens. CINV typically manifests during two well-defined time periods (acute and delayed phases). The acute phase is the first 24 hours after chemotherapy and is largely managed with 5-hydroxytryptamine 3 receptor antagonists. The delayed phase, a 5-day at-risk period during which patients are not often in direct contact with their health care provider, remains a significant unmet medical need. Neurokinin-1 (NK-1) receptor antagonists have demonstrated protection against acute and delayed CINV in patients treated with highly emetogenic chemotherapy and moderately emetogenic chemotherapy when used in combination with a 5-hydroxytryptamine 3 receptor antagonist and dexamethasone. Furthermore, recent data indicate that this protection is maintained over multiple treatment cycles. Rolapitant, a selective and long-acting NK-1 receptor antagonist, is approved as oral formulation for the prevention of delayed CINV in adults. This review discusses the differential pharmacology and clinical utility of rolapitant in preventing CINV compared with other NK-1 receptor antagonists.
\end{abstract}

Keywords: antiemetics, highly emetogenic chemotherapy, moderately emetogenic chemotherapy, delayed chemotherapy-induced nausea and vomiting, emesis, neurokinin-1 receptor antagonists

\section{Introduction}

\section{Management of chemotherapy-induced nausea and vomiting (CINV)}

Nausea and vomiting are the most feared side effects of cytotoxic chemotherapy ${ }^{1,2}$ and are most frequently reported following the administration of cisplatin, carboplatin, cyclophosphamide, and doxorubicin. ${ }^{3} \mathrm{CINV}$ can have a negative impact on healthrelated quality of life (QoL), ${ }^{4,5}$ compromise treatment outcomes, ${ }^{3,6,7}$ and increase health care resource utilization. ${ }^{8}$

CINV typically manifests during two time periods, the acute phase and the delayed phase, over a 5-day period. The acute phase occurs within the first 24 hours after chemotherapy and is largely mediated by 5 -hydroxytryptamine $3\left(5-\mathrm{HT}_{3}\right)$ receptors in the intestine. ${ }^{6}$ In this phase, free radicals generated after administration of chemotherapy induce the release of serotonin from enterochromaffin cells located in the intestinal mucosa. ${ }^{6}$ Serotonin then interacts with $5-\mathrm{HT}_{3}$ receptors located on vagal afferent nerves in the intestinal wall, which project to the area postrema and the nucleus tractus solitarius (NTS), stimulating the vomiting reflex. Acute CINV is therefore particularly sensitive to $5-\mathrm{HT}_{3}$ receptor antagonists; ${ }^{9}$ however, these agents have little impact on delayed CINV, ${ }^{9}$ suggesting that the pathophysiologic 
mechanisms during the delayed emetic phase may differ from those in the acute phase. The delayed phase of CINV starts on day 2 after chemotherapy and can last up to day 5 . Delayed CINV is predominantly driven by a central pathway involving the neurotransmitter/neuromodulator substance $\mathrm{P}$, which is a member of the mammalian tachykinin family of peptides. ${ }^{10}$ Substance $P$ is released from neurons in response to chemotherapy and binds to neurokinin-1 (NK-1) receptors in the area postrema and NTS, thereby mediating the induction of vomiting. ${ }^{11} \mathrm{NK}-1$ receptors are also located on vagal afferent terminals in the gastrointestinal tract, suggesting that substance $\mathrm{P}$, when released from enterochromaffin cells in response to chemotherapy, may also play a role in the acute phase of CINV. ${ }^{12}$ The critical role of substance $\mathrm{P}$ in delayed CINV is demonstrated by the effectiveness of NK-1 receptor antagonists in preventing CINV during this phase. ${ }^{6}$

While acute CINV is reasonably well managed with serotonin $\left(5-\mathrm{HT}_{3}\right)$ receptor antagonists in the majority of patients, ${ }^{13}$ delayed CINV continues to present a treatment challenge. ${ }^{14,15}$ Corticosteroids have been used for many years predominantly as prophylaxis against delayed CINV, although their exact mechanism of action is unknown. The antiemetic efficacy of 5- $\mathrm{HT}_{3}$ or dopamine receptor antagonists increases when they are used in combination with corticosteroids; ${ }^{16}$ therefore, these agents are typically administered concurrently. Benefits with olanzapine, an atypical antipsychotic drug that blocks dopaminergic, serotonergic, adrenergic, and histamine receptors, have been reported for delayed nausea control, particularly when it has been evaluated in combination with $5-\mathrm{HT}_{3}$ receptor antagonist and corticosteroids. ${ }^{17-19}$ The growing understanding of the role of substance $P$ in emesis led to the development of NK-1 receptor antagonists for the treatment of delayed CINV. The first oral NK-1 receptor antagonist, aprepitant, was approved in 2003, followed by fosaprepitant (a prodrug of aprepitant that is administered intravenously) in 2008 and netupitant (administered as a fixed oral combination with the $5-\mathrm{HT}_{3}$ receptor antagonist palonosetron) in 2014. In September 2015, oral rolapitant was approved by the US Food and Drug Administration (FDA) for use in combination with other antiemetic agents in adults for the prevention of delayed nausea and vomiting associated with initial and repeated courses of emetogenic cancer chemotherapy, including, but not limited to, highly emetogenic chemotherapy (HEC). In March 2016, a marketing authorization application for oral rolapitant was submitted to the European Medicines Agency. Several evidence-based guidelines for the prevention of CINV have been developed by international professional societies, ${ }^{3,20,21}$ which are rela-
Table I Summary of evidence-based guidelines for CINV prophylaxis with intravenous chemotherapy

\begin{tabular}{|c|c|}
\hline Emetic risk category & Guideline recommendation \\
\hline High (including & NK-I receptor antagonist $+5-\mathrm{HT}_{3}$ receptor \\
\hline anthracycline- & antagonist + dexamethasone $e^{3,20,21}$ \\
\hline cyclophosphamide & or \\
\hline combinations) & $\begin{array}{l}\text { Olanzapine }+5-\mathrm{HT}_{3} \text { receptor antagonist }+ \\
\text { dexamethasone }{ }^{3}\end{array}$ \\
\hline \multirow[t]{5}{*}{ Moderate } & 5- $\mathrm{HT}_{3}$ receptor antagonist + dexamethasone \\
\hline & or \\
\hline & $\begin{array}{l}\text { Olanzapine }+5-\mathrm{HT}_{3} \text { receptor antagonist }+ \\
\text { dexamethasone }{ }^{3}\end{array}$ \\
\hline & or \\
\hline & $\begin{array}{l}5-\mathrm{HT}_{3} \text { receptor antagonist }+ \\
\text { dexamethasone }^{20}\end{array}$ \\
\hline \multirow[t]{3}{*}{ Low } & Dexamethasone $e^{3,20,58}$ \\
\hline & or \\
\hline & $\begin{array}{l}\text { Dopamine receptor antagonist or } 5-\mathrm{HT}_{3} \\
\text { receptor antagonist }\end{array}$ \\
\hline Minimal & No prophylactic antiemetic ${ }^{3,20,58}$ \\
\hline
\end{tabular}

Notes: ${ }^{A} \mathrm{An}$ NK-I receptor antagonist should be added for patients with additional risk factors or who are failing $5-\mathrm{HT}_{3}$ receptor antagonist + dexamethasone. ${ }^{3}$ The NK-I receptor antagonist recommended in the American Society of Clinical Oncology guidelines is aprepitant. ${ }^{58}$

Abbreviations: 5-HT3, 5-hydroxytryptamine 3; CINV, chemotherapy-induced nausea and vomiting; NK-I, neurokinin-I.

tively consistent in their key recommendations (Table 1). In general, the guidelines recommend prescribing an NK-1 receptor antagonist along with a $5-\mathrm{HT}_{3}$ receptor antagonist and dexamethasone for the prevention of CINV in patients receiving $\mathrm{HEC}$ and a $5-\mathrm{HT}_{3}$ receptor antagonist and dexamethasone in patients receiving moderately emetogenic chemotherapy (MEC). ${ }^{3,20,21}$ The National Comprehensive Cancer Network and the American Society of Clinical Oncology also recommend the use of an NK-1 receptor antagonist in patients treated with MEC, particularly those with additional risk factors for CINV., ${ }^{3,21}$ This review provides a summary of the differential pharmacology and clinical utility of rolapitant, a long-acting NK-1 receptor antagonist, in the prevention of CINV.

\section{Overview of rolapitant pharmacology and comparison to other NK-I antagonists}

Rolapitant is a highly selective NK-1 receptor antagonist with high-affinity binding to the human NK-1 receptor $\left(\mathrm{K}_{\mathrm{i}}\right.$ $0.66 \mathrm{nmol} / \mathrm{L}$ ) over the NK-2 and -3 subtypes. ${ }^{22}$ The nanomolar affinity of rolapitant for NK-1 receptors is similar to that of other NK-1 receptor antagonists (Table 2). In a Phase I positron emission tomography (PET) study in 14 healthy individuals given a single oral dose of rolapitant, the drug 
Table 2 Pharmacologic and pharmacokinetic profile of marketed NK-I antagonists

\begin{tabular}{|c|c|c|c|c|c|c|c|c|}
\hline $\begin{array}{l}\text { NK-I receptor } \\
\text { antagonist }\end{array}$ & $\begin{array}{l}\text { Affinity } \\
\text { pKi }\end{array}$ & $\begin{array}{l}\text { Recommended } \\
\text { dosing }\end{array}$ & $\%$ RO (h) & $\begin{array}{l}\text { Plasma }[\mathrm{c}] \\
\text { at }>90 \% \text { RO }\end{array}$ & $\begin{array}{l}\text { Elimination } \\
\text { half-life (h) }\end{array}$ & $C_{\max }(n g / m L)$ & $\mathbf{T}_{\max }(\mathbf{h})$ & References \\
\hline Rolapitant & 9.1 & $\begin{array}{l}\text { Oral, single dose: } \\
180 \mathrm{mg} \text { on day } \\
\text { I; } 2 \mathrm{~h} \text { prior to } \\
\text { chemotherapy }\end{array}$ & $\begin{array}{l}\text { Striatum: } 73 \% \\
(120 \mathrm{~h}) \\
\text { Cortex: } 90 \% \\
(120 \mathrm{~h})\end{array}$ & $>348 \mathrm{ng} / \mathrm{mL}$ & $\sim 180$ & 968 & 4 & $22,23,26,27$ \\
\hline Aprepitant & 10.1 & $\begin{array}{l}\text { Multiple doses: } \\
\text { I } 25 \mathrm{mg} \text { orally on day } \\
\text { I and } 80 \mathrm{mg} \text { orally } \\
\text { on days } 2 \text { and } 3\end{array}$ & $\begin{array}{l}\text { Striatum }: \geq 99 \% \\
(4 \mathrm{~h}), \geq 99 \%(24 \mathrm{~h}), \\
\geq 97 \%(48 \mathrm{~h}), \text { and } \\
\sim 54 \%(120 \mathrm{~h})\end{array}$ & $\sim 21-100 \mathrm{ng} / \mathrm{mL}$ & $\sim 9-13$ & $\begin{array}{l}\text { I } 600 \text { on day I } \\
\text { I } 400 \text { on day } 3\end{array}$ & 4 & 24,29 \\
\hline Fosaprepitant ${ }^{\mathrm{b}}$ & 8.9 & $\begin{array}{l}\text { Single dose: } 150 \mathrm{mg} \\
\text { IV over } 20-30 \mathrm{~min} \text {, } \\
\sim 30 \text { min prior to } \\
\text { chemotherapy }\end{array}$ & $\begin{array}{l}\text { Striatum: } 100 \% \\
(0.5 \mathrm{~h}), 100 \% \\
(24 \mathrm{~h}), \geq 97 \% \\
(48 \mathrm{~h}) \text {, and } \sim 60 \% \\
(120 \mathrm{~h})\end{array}$ & $\sim 21-100 \mathrm{ng} / \mathrm{mL}$ & $\sim 9-13$ & 4200 & 0.5 & 24,28 \\
\hline Netupitant & 9.0 & $\begin{array}{l}\text { Single dose: } 300 \mathrm{mg} \text {. } \\
\text { It is administered } \\
\text { with } 0.5 \mathrm{mg} \\
\text { palonosetron, orally } \\
\text { on day I, I h prior } \\
\text { to chemotherapy }\end{array}$ & $\begin{array}{l}\text { Striatum: } 98 \% \\
(6 \mathrm{~h}), 91 \%(24 \mathrm{~h}) \text {, } \\
89 \%(48 \mathrm{~h}), 80 \% \\
(72 \mathrm{~h}), \text { and } 77 \% \\
(96 \mathrm{~h})\end{array}$ & $\sim 225 \mathrm{ng} / \mathrm{mL}$ & $\sim 96$ & 434 & 5 & 25,30 \\
\hline
\end{tabular}

Notes: ${ }^{2} \mathrm{~A}$ single oral dose of $165 \mathrm{mg}$ aprepitant was administered. ${ }^{24}{ }^{\text {b}}$ Fosaprepitant is converted to aprepitant within 30 min. Plasma [c], half-life, and $\mathrm{C}_{\max }$ values refer to aprepitant following administration of fosaprepitant.

Abbreviations: $C_{\text {max }}$, maximum concentration; h, hours; IV, intravenous; min, minutes; NK-I, neurokinin-I; pKi, -log Ki; RO, receptor occupancy; $T_{\text {max }}$, time to reach $C_{\max }$.

was shown to cross the blood-brain barrier and exhibited $>90 \%$ NK-1 receptor binding in the cortex and $73 \%$ receptor binding in the striatum when measured 5 days after administration. ${ }^{23} \mathrm{NK}-1$ receptor occupancy in the cortex was directly related to rolapitant dose and plasma concentration. A single administration of $200 \mathrm{mg}$ of rolapitant hydrochloride, which is equivalent to $180 \mathrm{mg}$ of rolapitant freebase, resulted in concentrations $>348 \mathrm{ng} / \mathrm{mL}$ at 120 hours, which corresponds to $>90 \%$ NK-1 receptor occupancy (Table 2). Similar PET studies have evaluated brain NK-1 receptor occupancy for marketed NK-1 receptor antagonists in healthy subjects (Table 2). ${ }^{24,25}$ In one study, ${ }^{24}$ receptor occupancy in the striatum was $\sim 54 \%$ for aprepitant (165 mg; single oral administration) and $\sim 60 \%$ for fosaprepitant ( $150 \mathrm{mg}$; single IV administration) on day 5. In the same study, plasma concentrations for aprepitant and fosaprepitant were 142 and $92 \mathrm{ng} / \mathrm{mL}$ on day 3 , and they were $<10 \mathrm{ng} / \mathrm{mL}$ for both drugs on day 4 . In a separate study, ${ }^{25}$ receptor occupancy in the striatum for netupitant ( $300 \mathrm{mg}$; single oral administration) was $89 \%$ on day 2 and $77 \%$ on day 4 , corresponding to an average of 93 and $41 \mathrm{ng} / \mathrm{mL}$ plasma concentration, respectively.

Pharmacokinetic analyses performed on healthy fasting individuals who received a single dose of rolapitant (180 mg) showed that the maximum plasma concentration was $968 \mathrm{ng} / \mathrm{mL}$, with a time to maximum concentration of $\sim 4$ hours. ${ }^{26}$ Administration of a high-fat meal did not have any significant effect on the pharmacokinetic profile of rolapitant. ${ }^{26}$ At the recommended doses, oral administration of aprepitant, fosaprepitant, and netupitant resulted in peak plasma concentrations of $1600-1400 \mathrm{ng} / \mathrm{mL}$ (at 4 hours), $4200 \mathrm{ng} / \mathrm{mL}$ (at 0.5 hour), and $434 \mathrm{ng} / \mathrm{mL}$ (at 5 hours), respectively.

The half-life of rolapitant (169-183 hours) $)^{26,27}$ is longer than that of the NK-1 receptor antagonists aprepitant, fosaprepitant (9-13 hours), ${ }^{28,29}$ and netupitant ( $80 \pm 20$ hours) ${ }^{30}$ (Table 2), and it supports a single-dose regimen that per the US label is administered 1-2 hours prior to chemotherapy for the prevention of CINV across the entire 5-day at-risk period. Furthermore, rolapitant is primarily metabolized by the cytochrome P450 (CYP) enzyme CYP3A4 to form M19 (SCH720 881), its major circulating metabolite. ${ }^{31}$ Median time to maximum concentration for M19 is 120 hours, and mean half-life of M19 is 158 hours. ${ }^{26}$ Multiple covariates including age, gender, race, chemotherapy regimen, creatinine clearance, concomitant medications, and neutrophil count had no effect on the pharmacokinetics of rolapitant. ${ }^{32}$

\section{Clinical utility of rolapitant and comparison to other NK-I receptor antagonists}

The efficacy of NK-1 receptor antagonists for the prevention of delayed CINV when used in combination with a $5-\mathrm{HT}_{3}$ receptor antagonist and a corticosteroid has been established 
in a number of randomized controlled trials. A summary of complete response $(\mathrm{CR})$ rates (defined as no emesis and no use of rescue medication) across agents is shown in Table 3.

The first group of trials to evaluate the addition of aprepitant to ondansetron plus dexamethasone reported increased protection against delayed CINV in patients receiving both $\mathrm{HEC}^{33,34}$ and MEC. ${ }^{35}$ For example, in a Phase III, randomized, double-blind HEC study in patients scheduled to receive treatment with high-dose cisplatin, CR rates during the delayed phase were $68 \%$ in the aprepitant group and 47\% (Table 3 ) in the active control group $(P<0.001)$, which was administered as intravenous ondansetron $32 \mathrm{mg}$ and oral dexamethasone $20 \mathrm{mg}$ on day 1 and oral dexamethasone $8 \mathrm{mg}$ twice daily on days $2-4 .{ }^{34}$ Although aprepitant was associated with an improvement in the proportion of patients who did not experience delayed vomiting, between-treatment differences in rates of no significant nausea ( $73 \%$ vs $65 \%$ ) were not statistically significant (data not shown). In a similar HEC study in patients receiving high-dose cisplatin, $\mathrm{CR}$ rates during the delayed phase were $75 \%$ in the aprepitant group and 56\% (Table 3$)$ in the active control group $(P<0.001) .{ }^{33}$ As in the

Table 3 Summary of complete response (\%) in cycle I of chemotherapy after administration of marketed NK-I receptor antagonists

\begin{tabular}{|c|c|c|c|c|c|}
\hline $\begin{array}{l}\text { Treatments } \\
\text { drug vs control }\end{array}$ & Chemotherapy & Phase & $\begin{array}{l}\text { Complete response } \\
\text { drug vs control }\end{array}$ & $P$-value & Reference \\
\hline $\begin{array}{l}\text { Aprepitant vs ondansetron }+ \\
\text { dexamethasone }\end{array}$ & HEC; high-dose cisplatin & $\begin{array}{l}\text { Acute phase }(0-24 \mathrm{~h}) \\
\text { Delayed phase }(24-120 \mathrm{~h}) \\
\text { Overall phase }(0-120 \mathrm{~h})\end{array}$ & $\begin{array}{l}89 \text { vs } 78 \\
75 \text { vs } 56 \\
73 \text { vs } 52\end{array}$ & $\begin{array}{l}\leq 0.001 \\
\leq 0.001 \\
\leq 0.001\end{array}$ & 33 \\
\hline $\begin{array}{l}\text { Aprepitant vs ondansetron }+ \\
\text { dexamethasone }\end{array}$ & HEC; high-dose cisplatin & $\begin{array}{l}\text { Acute phase }(0-24 \mathrm{~h}) \\
\text { Delayed phase }(24-120 \mathrm{~h}) \\
\text { Overall phase }(0-120 \mathrm{~h})\end{array}$ & $\begin{array}{l}83 \text { vs } 68 \\
68 \text { vs } 47 \\
63 \text { vs } 43\end{array}$ & $\begin{array}{l}\leq 0.001 \\
\leq 0.001 \\
\leq 0.001\end{array}$ & 34 \\
\hline $\begin{array}{l}\text { Aprepitant vs ondansetron }+ \\
\text { dexamethasone }\end{array}$ & MEC; with AC & $\begin{array}{l}\text { Acute phase }(0-24 \mathrm{~h}) \\
\text { Delayed phase }(24-120 \mathrm{~h}) \\
\text { Overall phase }(0-120 \mathrm{~h})\end{array}$ & $\begin{array}{l}84 \text { vs } 72 \\
65 \text { vs } 53 \\
63 \text { vs } 47\end{array}$ & $\begin{array}{l}\leq 0.05 \\
\leq 0.05 \\
\leq 0.05\end{array}$ & 35 \\
\hline $\begin{array}{l}\text { Aprepitant vs ondansetron }+ \\
\text { dexamethasone }\end{array}$ & MEC; non-AC & $\begin{array}{l}\text { Acute phase }(0-24 \mathrm{~h}) \\
\text { Delayed phase }(24-120 \mathrm{~h}) \\
\text { Overall phase }(0-120 \mathrm{~h})\end{array}$ & $\begin{array}{l}93 \text { vs } 88 \\
76 \text { vs } 69 \\
74 \text { vs } 65\end{array}$ & $\begin{array}{l}\text { NS } \\
\text { NS } \\
\text { NS }\end{array}$ & 35 \\
\hline $\begin{array}{l}\text { Fosaprepitant vs aprepitant }+ \\
\text { ondansetron }+ \text { dexamethasone }\end{array}$ & $\begin{array}{l}\text { HEC; first course } \\
\text { cisplatin-based } \\
\text { chemotherapy }\left(\geq 70 \mathrm{mg} / \mathrm{m}^{2}\right)\end{array}$ & $\begin{array}{l}\text { Acute phase }(0-24 \mathrm{~h}) \\
\text { Delayed phase }(24-120 \mathrm{~h}) \\
\text { Overall phase }(0-120 \mathrm{~h})\end{array}$ & $\begin{array}{l}72 \text { vs } 72 \\
89 \text { vs } 88 \\
74 \text { vs } 74\end{array}$ & $\begin{array}{l}\text { NS } \\
\text { NS } \\
\text { NS }\end{array}$ & 37 \\
\hline $\begin{array}{l}\text { Fosaprepitant vs ondansetron + } \\
\text { dexamethasone }\end{array}$ & MEC; non-AC & $\begin{array}{l}\text { Acute phase }(0-24 \mathrm{~h}) \\
\text { Delayed phase }(24-120 \mathrm{~h}) \\
\text { Overall phase }(0-120 \mathrm{~h})\end{array}$ & $\begin{array}{l}93 \text { vs } 91 \\
79 \text { vs } 68 \\
77 \text { vs } 67\end{array}$ & $\begin{array}{l}\text { NS } \\
\leq 0.001 \\
\leq 0.001\end{array}$ & 38 \\
\hline $\begin{array}{l}\text { NEPA vs palonosetron }+ \\
\text { dexamethasone }\end{array}$ & $\begin{array}{l}\text { HEC; cisplatin-based } \\
\text { chemotherapy }\end{array}$ & $\begin{array}{l}\text { Acute phase }(0-24 \mathrm{~h}) \\
\text { Delayed phase }(24-120 \mathrm{~h}) \\
\text { Overall phase }(0-120 \mathrm{~h})\end{array}$ & $\begin{array}{l}98 \text { vs } 90 \\
90 \text { vs } 80 \\
90 \text { vs } 76\end{array}$ & $\begin{array}{l}\leq 0.01 \\
\leq 0.05 \\
\leq 0.01\end{array}$ & 39 \\
\hline $\begin{array}{l}\text { NEPA vs palonosetron + } \\
\text { dexamethasone }\end{array}$ & HEC; with AC & $\begin{array}{l}\text { Acute phase }(0-24 \mathrm{~h}) \\
\text { Delayed phase }(24-120 \mathrm{~h}) \\
\text { Overall phase }(0-120 \mathrm{~h})\end{array}$ & $\begin{array}{l}88 \text { vs } 85 \\
77 \text { vs } 69 \\
74 \text { vs } 67\end{array}$ & $\begin{array}{l}\leq 0.05 \\
\leq 0.01 \\
\leq 0.01\end{array}$ & 40 \\
\hline $\begin{array}{l}\text { Rolapitant vs ondansetron + } \\
\text { dexamethasone }\end{array}$ & $\begin{array}{l}\text { HEC (Phase II); } \\
\text { cisplatin-based } \\
\text { chemotherapy }\left(\geq 70 \mathrm{mg} / \mathrm{m}^{2}\right)\end{array}$ & $\begin{array}{l}\text { Acute phase }(0-24 \mathrm{~h}) \\
\text { Delayed phase }(24-120 \mathrm{~h}) \\
\text { Overall phase }(0-120 \mathrm{~h})\end{array}$ & $\begin{array}{l}88 \text { vs } 67 \\
64 \text { vs } 49 \\
63 \text { vs } 47\end{array}$ & $\begin{array}{l}\leq 0.001 \\
\leq 0.05 \\
\leq 0.05\end{array}$ & 41 \\
\hline $\begin{array}{l}\text { Rolapitant vs granisetron + } \\
\text { dexamethasone }\end{array}$ & $\begin{array}{l}\text { HEC I; first course } \\
\text { (cisplatin-based } \\
\text { chemotherapy; } \geq 60 \mathrm{mg} / \mathrm{m}^{2} \text { ) }\end{array}$ & $\begin{array}{l}\text { Acute phase }(0-24 \mathrm{~h}) \\
\text { Delayed phase }(24-120 \mathrm{~h}) \\
\text { Overall phase }(0-120 \mathrm{~h})\end{array}$ & $\begin{array}{l}84 \text { vs } 74 \\
73 \text { vs } 58 \\
70 \text { vs } 56\end{array}$ & $\begin{array}{l}\leq 0.01 \\
\leq 0.001 \\
\leq 0.01\end{array}$ & 42 \\
\hline $\begin{array}{l}\text { Rolapitant vs granisetron + } \\
\text { dexamethasone }\end{array}$ & $\begin{array}{l}\text { HEC 2; first course } \\
\text { of cisplatin-based } \\
\text { chemotherapy }\left(\geq 60 \mathrm{mg} / \mathrm{m}^{2}\right)\end{array}$ & $\begin{array}{l}\text { Acute phase }(0-24 \mathrm{~h}) \\
\text { Delayed phase }(24-120 \mathrm{~h}) \\
\text { Overall phase }(0-120 \mathrm{~h})\end{array}$ & $\begin{array}{l}83 \text { vs } 79 \\
70 \text { vs } 62 \\
68 \text { vs } 60\end{array}$ & $\begin{array}{l}\text { NS } \\
\leq 0.05 \\
\text { NS }\end{array}$ & 42 \\
\hline $\begin{array}{l}\text { Rolapitant vs granisetron }+ \\
\text { dexamethasone }\end{array}$ & MEC; with AC & $\begin{array}{l}\text { Acute phase }(0-24 \mathrm{~h}) \\
\text { Delayed phase }(24-120 \mathrm{~h}) \\
\text { Overall phase }(0-120 \mathrm{~h})\end{array}$ & $\begin{array}{l}77 \text { vs } 77 \\
67 \text { vs } 60 \\
63 \text { vs } 55\end{array}$ & $\begin{array}{l}\text { NS } \\
\leq 0.001 \\
\leq 0.001\end{array}$ & 43 \\
\hline $\begin{array}{l}\text { Rolapitant vs granisetron }+ \\
\text { dexamethasone }\end{array}$ & $\begin{array}{l}\text { MEC; non-AC } \\
\text { carboplatin-based }\end{array}$ & $\begin{array}{l}\text { Acute phase }(0-24 \mathrm{~h}) \\
\text { Delayed phase }(24-120 \mathrm{~h}) \\
\text { Overall phase }(0-120 \mathrm{~h})\end{array}$ & $\begin{array}{l}92 \text { vs } 88 \\
82 \text { vs } 66 \\
80 \text { vs } 65\end{array}$ & $\begin{array}{l}\text { NS } \\
<0.001 \\
<0.001\end{array}$ & 44 \\
\hline
\end{tabular}

Abbreviations: AC, anthracycline-cyclophosphamide-based chemotherapy; h, hours; HEC, highly emetogenic chemotherapy; MEC, moderately emetogenic chemotherapy; NEPA, netupitant plus palonosetron; NK-I, neurokinin-I; NS, not significant. 
previous study, aprepitant had a significant benefit with respect to rates of emesis but not nausea. Significant differences between aprepitant and active control on delayed CINV were also reported for $\mathrm{CR}$ rates in a population including patients receiving MEC and patients receiving anthracycline-cyclophosphamide-based chemotherapy (AC) (65\% for aprepitant vs 53\% for active control), with AC classified at the time as MEC, but not in patients receiving MEC. ${ }^{35}$ In an open-label, randomized Phase III trial, significant differences in CR rates between the aprepitant group and the active control group were reported on overall and delayed CINV in patients with colorectal cancer receiving oxaliplatin-based chemotherapy. ${ }^{36}$

Single-dose fosaprepitant was approved for use in delayed CINV based on the results of a Phase III noninferiority trial versus aprepitant (administered once daily for 3 days) in patients receiving HEC and treated with ondansetron and dexamethasone. ${ }^{37}$ No significant difference in $\mathrm{CR}$ rates for the acute, delayed, and overall phases was reported between the fosaprepitant and aprepitant arms in patients receiving cisplatin-based chemotherapy. ${ }^{37}$ A recent Phase III study evaluated the addition of fosaprepitant to ondansetron and dexamethasone in patients receiving non-AC MEC. ${ }^{38}$ In this randomized, double-blind, placebocontrolled study, fosaprepitant significantly improved rates of delayed CR ( $79 \%$ vs $68 \%$; $P \leq 0.001$; Table 3 ). The impact of fosaprepitant on nausea in the delayed phase of this study was not described.

In 2014, netupitant was approved for the prevention of CINV. Netupitant is administered as a fixed oral combination with palonosetron (NEPA), and this formulation has been evaluated in randomized controlled trials in patients receiving cisplatin-based $\mathrm{HEC}^{39}$ and $\mathrm{HEC}$ with AC (considered MEC at the time of the study). ${ }^{40}$ In the Phase II cisplatin-based HEC study, ${ }^{39}$ a CR during the delayed phase was reported in $90 \%$ of the NEPA plus dexamethasone group compared with $80 \%$ (Table 3 ) of the control group receiving palonosetron plus dexamethasone $(P \leq 0.05)$, with significant benefits reported in terms of both vomiting and nausea. ${ }^{39}$ In the Phase III HEC with $\mathrm{AC}$ study, ${ }^{40}$ the percentage of patients with a CR during the delayed phase was significantly higher with NEPA plus dexamethasone than with palonosetron plus dexamethasone (77\% vs 69\%; $P \leq 0.01$; Table 3$).{ }^{40}$ Likewise, NEPA plus dexamethasone was associated with significantly higher rates of no emesis ( $82 \%$ vs $75 \% ; P=0.004)$ and no significant nausea (77\% vs $71 \% ; P=0.014)$.

The efficacy of rolapitant in preventing CINV when added to granisetron, a $5-\mathrm{HT}_{3}$ receptor antagonist, plus dexamethasone has been evaluated in one Phase II study in patients receiving $\mathrm{HEC},{ }^{41}$ in two Phase III clinical trials in patients receiving $\mathrm{HEC}^{42}$ (HEC 1 and HEC 2 studies), and one Phase III clinical trial in patients receiving MEC or AC (which was initially considered to be MEC and is now classified by all major guideline groups as HEC). ${ }^{43}$ In all four studies, rolapitant significantly improved CR in the delayed phase compared with the active control (Table 3 ). For example, in the Phase III HEC 1 study (Table 3), CR in the delayed phase was $73 \%$ for rolapitant recipients versus $58 \%$ for active control recipients (odds ratio [OR]: 1.9; 95\% confidence interval $[\mathrm{CI}]: 1.3-2.7 ; P=0.0006) .{ }^{42}$ The addition of rolapitant to active therapy also produced a significantly higher rate of no emesis and no clinically significant nausea in the delayed phase. Similar results were obtained in the Phase III HEC 2 study (Table 3). ${ }^{42}$ In the Phase III MEC study in patients treated with $\mathrm{AC}$, the addition of rolapitant improved $\mathrm{CR}$ rates in the delayed phase compared with active control (67\% vs 60\%; OR: 1.4 ; 95\% CI: $1.0-1.9 ; P=0.0465$; Table 3) ${ }^{43}$ with significant benefits noted in the prevention of vomiting but not of nausea. The benefit of rolapitant on $\mathrm{CR}$ in the delayed phase was maintained in patients who were not treated with $\mathrm{AC}$ and received carboplatin-based chemotherapy ( $82 \%$ for rolapitant vs $66 \%$ for active control; $P<0.001) .{ }^{44}$ An additional analysis in the subgroup of patients treated with carboplatin-based chemotherapy found that the absolute benefit observed with rolapitant (the absolute difference between the proportion of rolapitant and active control respondents) was 15.3 percentage points for $\mathrm{CR}$ in the delayed phase. ${ }^{44}$

These four clinical trials demonstrated that a single $180 \mathrm{mg}$ oral dose of rolapitant administered $\sim 1-2$ hours prior to $\mathrm{HEC}$ or MEC in combination with a $5-\mathrm{HT}_{3}$ receptor antagonist and dexamethasone provided superior CINV protection across the delayed phase compared with a $5-\mathrm{HT}_{3}$ receptor antagonist and dexamethasone alone. ${ }^{42,43}$ Based on these results, the National Comprehensive Cancer Network added oral rolapitant to their clinical practice guidelines for preventing CINV as a treatment option for patients receiving HEC and MEC, and it is recommended for the subset of patients with additional risk factors or treatment failure with a steroid plus $5-\mathrm{HT}_{3}$ antagonist alone. ${ }^{35}$ In addition to recommending rolapitant as part of the prophylactic regimen for patients receiving HEC, a 2016 update to the antiemetic guidelines from the Multinational Association of Supportive Care in Cancer/European Society for Medical Oncology recommended rolapitant in patients receiving carboplatinbased MEC. ${ }^{37}$ 


\section{Safety and tolerability of rolapitant and comparison to other NK-I receptor antagonists}

NK-1 receptor antagonists are generally well tolerated. The most commonly reported treatment-emergent adverse events (TEAEs) with NK-1 receptor antagonists in clinical trials included headache, constipation, fatigue, and hiccups, which appeared with a similar frequency as seen in active control groups (Table 4). ${ }^{6}$ The adverse event (AE) profile of NK-1 receptor antagonists as a class, mirrors that associated with other classes of antiemetic agents, ${ }^{45}$ with the most commonly reported TEAEs being fatigue, constipation, neutropenia, alopecia, diarrhea, and headache. ${ }^{46}$

Rolapitant has a similar safety and tolerability profile to other NK-1 receptor antagonists, with headache, constipation, fatigue, and hiccups among the most commonly reported TEAEs ${ }^{41-43}$ (Table 4). In Phase II and III trials, rolapitant had a similar frequency of AEs to those seen in the active control groups. Grade 1-2 AEs were reported in
$<10 \%$ of patients. No patient had a serious TEAE, nor did any patient die from a TEAE. When assessed across multiple cycles of chemotherapy, ${ }^{47}$ rolapitant was well tolerated, with an incidence of TEAEs similar to that seen in cycle 1 . The incidence of TEAEs did not increase with increasing cycles of chemotherapy, and cumulative toxicity was not evident. In an integrated safety analysis of the three Phase III and one Phase II randomized trials, the incidence of TEAEs was similar between the rolapitant and control arms in the subgroup of patients who used concomitant CYP2D6, breast cancer resistance protein (BCRP), or CYP3A4 substrate drugs. ${ }^{46}$ This suggests that the risk of drug interactions is low when rolapitant is coadministered with such drugs, although caution should be exercised when using rolapitant concomitantly with CYP2D6, BCRP, and P-glycoprotein substrates with a narrow therapeutic index. Unlike other marketed NK-1 receptor antagonists, ${ }^{28-30}$ rolapitant does not inhibit or induce CYP3A4 and has not shown effects on the pharmacokinetics of the sensitive CYP3A4 substrate midazolam. ${ }^{31}$ Thus, dose

Table 4 Safety and tolerability of marketed NK-I receptor antagonists

\begin{tabular}{|c|c|c|c|c|c|}
\hline NK-I receptor antagonist & Chemotherapy & $\begin{array}{l}\text { Incidence of } \\
\text { drug-related AEs }\end{array}$ & $\begin{array}{l}\text { Difference relative } \\
\text { to control }\end{array}$ & $\begin{array}{l}\text { Potential drug-drug } \\
\text { interactions }\end{array}$ & References \\
\hline \multirow[t]{8}{*}{ Rolapitant } & HEC & Dyspepsia $(<1 \%)$ & No & CYP2D6a & $26,42,43$ \\
\hline & & Headache $(<1 \%)$ & & $\mathrm{BCRP}$ & \\
\hline & & Constipation $(<1 \%)$ & & & \\
\hline & & Hiccups (<I\%) & & & \\
\hline & MEC & Constipation (3\%) & No & & \\
\hline & & Fatigue (3\%) & & & \\
\hline & & Dizziness (I\%) & & & \\
\hline & & Headache $(2 \%)$ & & & \\
\hline \multirow[t]{8}{*}{ Aprepitant/fosaprepitant } & HEC & Anorexia (3\%) & No & CYP3A4' substrates & 28,29,33-35 \\
\hline & & Fatigue (3\%) & & CYP3A4 inhibitors & \\
\hline & & Constipation (2\%) & & CYP3A4 $4^{\mathrm{e}}$ inducers & \\
\hline & & Diarrhea (2\%) & & Warfarin & \\
\hline & MEC & Constipation $(<1 \%)$ & No & Hormonal & \\
\hline & & Fatigue $(<1 \%)$ & & contraceptives $^{g}$ & \\
\hline & & Headache $(<1 \%)$ & & & \\
\hline & & Diarrhea $(<1 \%)$ & & & \\
\hline \multirow[t]{6}{*}{ Netupitant } & HEC & Hiccups (5\%) & No & CYP3A4' substrates & $30,39,59$ \\
\hline & & Leukocytosis (2\%) & & CYP3A4 inhibitors & \\
\hline & & ALT increased (2\%) & & CYP3A4 $4^{\mathrm{e}}$ inducers & \\
\hline & & Bundle branch block (2\%) & & & \\
\hline & MEC & Headache $(3 \%)$ & No & & \\
\hline & & Constipation (2\%) & & & \\
\hline
\end{tabular}

Notes: ${ }^{a}$ CYP2D6 substrates with a narrow therapeutic index (e.g., dextromethorphan, thioridazine, pimozide) may increase plasma concentration of concomitant drug with potential for AEs. 'BCRP substrates with a narrow therapeutic index (e.g., methotrexate, topotecan, irinotecan, rosuvastatin) may increase plasma concentration of concomitant drug. ' $\mathrm{C}$ YP3A4 substrates (e.g., pimozide, benzodiazepines, dexamethasone, methylprednisolone, some chemotherapeutics) may increase plasma concentration of concomitant drug. 'Strong or moderate CYP3A4 inhibitors (e.g., ketoconazole, itraconazole, nefazodone, troleandomycin, clarithromycin, ritonavir, nelfinavir, diltiazem) may increase plasma concentrations of aprepitant or netupitant with increased risk of AEs. eStrong CYP3A4 inducers (e.g., rifampin, carbamazepine, phenytoin) may decrease plasma concentrations of aprepitant or netupitant and reduce efficacy. IInternational normalized ratio of prothrombin time may decrease. ${ }^{8 E f f i c a c y}$ may be decreased for up to 28 days following last dose.

Abbreviations: AEs, adverse events; ALT, alanine aminotransferase; BCRP, breast cancer resistance protein; CYP, cytochrome P450; HEC, highly emetogenic chemotherapy; MEC, moderately emetogenic chemotherapy; NK-I, neurokinin-I. 
adjustments are not required when rolapitant is concomitantly administered with other drugs metabolized by CYP34A such as dexamethasone. ${ }^{26}$ However, strong CYP3A4 inducers such as rifampin may significantly reduce plasma concentrations of rolapitant; therefore, concurrent use should be avoided (Table 4). ${ }^{26}$ Rolapitant is also a moderate inhibitor of the CYP2D6 enzyme, BCRP, and P-glycoprotein, meaning that concomitant use of substrates of these proteins with a narrow therapeutic index should be avoided or the patient should be monitored for adverse reactions (Table 4). ${ }^{26}$ Overall, the low risk of drug-drug interactions with rolapitant compared with other NK-1 receptor antagonists makes this drug particularly safe to use and potentially beneficial in older people who typically take multiple medications.

\section{Impact of rolapitant on QoL}

CINV negatively affects patient QoL. Poorly controlled nausea and vomiting is one of the most dreaded side effects of chemotherapy, ranking worse than depression, fatigue, and diarrhea, with poorly controlled CINV ranking second only to death. ${ }^{2}$ The impacts of CINV are manifested not only in a patient's QoL but also in medical costs, use of health care resources, and compliance with further chemotherapy. ${ }^{4,8,12,48-50}$

Surveys indicate that oncologists and oncology nurses can accurately predict the incidence of acute CINV after HEC; however, there is a perception gap between health professionals and patients with respect to the incidence of delayed CINV after HEC that is often underestimated. In one study, the predicted incidence of delayed nausea was 39\% (95\% CI: $30 \%-48 \%$ ), whereas the observed incidence was $60 \%(95 \%$ CI: $48 \%-72 \%$ ), and the predicted incidence of delayed vomiting was $22 \%$ (95\% CI: $12 \%-31 \%$ ), whereas the observed incidence was 50\% (95\% CI: 37\%-63\%). ${ }^{14}$ Delayed CINV has also been underestimated in patients receiving MEC. ${ }^{14,51}$ Misperceptions regarding the incidence of delayed CINV may have implications for treatment. For example, in a UK study, patients who experienced acute vomiting in cycle 1 were significantly more likely to have a change in antiemetic therapy in subsequent cycles; by contrast, delayed vomiting or nausea at any stage did not lead to changes in subsequent antiemetic regimens. ${ }^{52}$

Delayed CINV has a significant detrimental effect on a patient's daily life, ${ }^{4,5,53}$ even in the absence of acute CINV. In a representative sample of 298 treatment-naive patients receiving HEC or MEC and given CINV prophylaxis under then-current patterns of clinical practice, the impact of CINV on daily life was assessed using the Functional Living IndexEmesis (FLIE) questionnaire on day 6 of cycle $1 .{ }^{4}$ Only $32 \%$ of patients who experienced delayed vomiting without acute vomiting reported that CINV had no or minimal impact on daily life, similar to the proportion of patients who experienced only acute vomiting (30\%). In the same study, $80 \%$ of patients who experienced acute nausea without delayed nausea reported that emesis did not affect their daily life; by contrast, only $56 \%$ of those who experienced delayed nausea without acute nausea reported no or minimal impact. The FLIE is an 18-item questionnaire ${ }^{54,55}$ comprising two domains (nausea and vomiting); in each domain, the patient answers one question on the magnitude of the symptom (nausea or vomiting) followed by eight questions to assess the impact of the symptom on the patient's ability to enjoy meals/liquids, prepare meals/do household tasks, perform daily functions, and engage in usual recreation/leisure activities, as well as his/her willingness to spend time with family and friends and the extent to which symptoms have caused personal hardship. ${ }^{54,55}$ Patient responses are recorded using a sevenpoint visual analog scale, with higher scores corresponding to a higher QoL and an average item score $>6$ (or FLIE total score $>108$ ) defined as no impact of CINV on daily life. In a prospective, placebo-controlled, randomized, double-blind Phase III trial conducted in patients with multiple myeloma undergoing autologous transplantation after high-dose melphalan conditioning, aprepitant significantly improved QoL compared with active control. Mean total FLIE score ( \pm standard deviation $[S D]$ ) was $114( \pm 18)$ for the aprepitant group and $106( \pm 26)$ for the active control group $(P<0.001)$. A pooled analysis of Phase III trials (HEC 1, HEC 2, and MEC) demonstrated that rolapitant significantly improved QoL in patients receiving both HEC and MEC compared with active control. ${ }^{56,57}$ In the HEC studies, the mean $( \pm \mathrm{SD})$ FLIE total score was $114( \pm 17)$ for the rolapitant group and 109 ( \pm 24$)$ for the active control group $(P<0.001)$; in the MEC study, it was $113( \pm 20)$ for the rolapitant group and $109( \pm 23)$ for the active control group $(P>0.001)$. Overall, these Phase III clinical trials demonstrated that a single oral administration of rolapitant significantly improved patient QoL.

\section{Conclusion and place in therapy}

Therapy for delayed CINV, the 5-day at-risk period during which patients are not often in direct contact with caregivers, remains a significant unmet medical need for multiple reasons. For example, appropriate prophylactic antiemetics may be inadequately prescribed because of an underestimation of delayed CINV control or patients may be nonadherent to prescribing instructions when pills need to be taken at home. The discovery and development of NK-1 receptor 
antagonists bring additional treatment options for patients at risk for CINV. The recent approval of rolapitant for the prevention of delayed CINV in combination with other antiemetic agents may provide adult patients with significant benefits beyond those of previously approved NK-1 receptor antagonists. Specifically, the combination of the longer half-life and sustained efficacy of rolapitant, compared with these other agents, and its single oral administration prior to chemotherapy may lead to better control while on treatment. This is particularly important given that failure to protect against CINV during the first cycle of chemotherapy is the most significant independent risk factor for delayed CINV during subsequent cycles. Additionally, the mild-to-moderate adverse effects of rolapitant, which were not significantly different than those of the active controls, and the lack of interactions with drugs metabolized by CYP34A such as dexamethasone may also be beneficial, particularly in older patients who tend to take more medications.

\section{Acknowledgments}

Ruggero Galici, $\mathrm{PhD}$ (Ashfield Healthcare, Haddam, CT, USA), drafted and revised the manuscript based on content outline provided by the author. Shannon Davis (Ashfield Healthcare) copyedited and styled the manuscript per journal requirements.

\section{Author contribution}

Dr Rapoport was responsible for the conception and analysis of this review, for revising the scientific and medical content and drafts, and for approving the final version for publication; he is accountable for the accuracy and integrity of the work.

\section{Disclosure}

Dr Rapoport has received honoraria to participate at advisory boards for TESARO, Merck, and Heron, and he has received research funding from Merck and TESARO. Medical writing and editorial support were funded by TESARO. The author reports no other conflicts of interest.

\section{References}

1. de Boer-Dennert M, de Wit R, Schmitz PI, et al. Patient perceptions of the side-effects of chemotherapy: the influence of 5HT3 antagonists. Br J Cancer. 1997;76(8):1055-1061.

2. Sun CC, Bodurka DC, Weaver CB, et al. Rankings and symptom assessments of side effects from chemotherapy: insights from experienced patients with ovarian cancer. Support Care Cancer. 2005;13(4):219-227.

3. National Comprehensive Cancer Network [homepage on the Internet]. NCCN Clinical Practice Guidelines in Oncology: Antiemesis. Version 1. 2016. Available from: www.nccn.org. Accessed December 28, 2016.

4. Bloechl-Daum B, Deuson RR, Mavros P, Hansen M, Herrstedt J. Delayed nausea and vomiting continue to reduce patients' quality of life after highly and moderately emetogenic chemotherapy despite antiemetic treatment. J Clin Oncol. 2006;24(27):4472-4478.
5. Hilarius DL, Kloeg PH, van der Wall E, van den Heuvel JJ, Gundy CM, Aaronson NK. Chemotherapy-induced nausea and vomiting in daily clinical practice: a community hospital-based study. Support Care Cancer. 2012;20(1):107-117.

6. Navari RM. The safety of antiemetic medications for the prevention of chemotherapy-induced nausea and vomiting. Expert Opin Drug Saf. 2016;15(3):343-356.

7. Vidall C, Dielenseger P, Farrell C, et al. Evidence-based management of chemotherapy-induced nausea and vomiting: a position statement from a European cancer nursing forum. Ecancermedicalscience. 2011;5:211.

8. Schwartzberg L, Harrow B, Lal LS, Radtchenko J, Lyman GH. Resource utilization for chemotherapy-induced nausea and vomiting events in patients with solid tumors treated with antiemetic regimens. Am Health Drug Benefits. 2015;8(5):273-282.

9. Aapro M, Blower P. 5-hydroxytryptamine type-3 receptor antagonists for chemotherapy-induced and radiotherapy-induced nausea and emesis: can we safely reduce the dose of administered agents? Cancer. 2005;104(1):1-18.

10. Garcia-Recio S, Gascon P. Biological and pharmacological aspects of the NK1-receptor. Biomed Res Int. 2015;2015:495704.

11. Armstrong DM, Pickel VM, Joh TH, Reis DJ, Miller RJ. Immunocytochemical localization of catecholamine synthesizing enzymes and neuropeptides in area postrema and medial nucleus tractus solitarius of rat brain. J Comp Neurol. 1981;196(3):505-517.

12. Hesketh PJ. Chemotherapy-induced nausea and vomiting. $N$ Engl $J$ Med. 2008;358(23):2482-2494.

13. Jordan K, Hinke A, Grothey A, et al. A meta-analysis comparing the efficacy of four 5-HT3-receptor antagonists for acute chemotherapyinduced emesis. Support Care Cancer. 2007;15(9):1023-1033.

14. Grunberg SM, Deuson RR, Mavros P, et al. Incidence of chemotherapy-induced nausea and emesis after modern antiemetics. Cancer. 2004;100(10):2261-2268.

15. Hsieh RK, Chan A, Kim HK, et al. Baseline patient characteristics, incidence of CINV, and physician perception of CINV incidence following moderately and highly emetogenic chemotherapy in Asia Pacific countries. Support Care Cancer. 2015;23(1):263-272.

16. Grunberg SM. Antiemetic activity of corticosteroids in patients receiving cancer chemotherapy: dosing, efficacy, and tolerability analysis. Ann Oncol. 2007;18(2):233-240.

17. Navari RM, Gray SE, Kerr AC. Olanzapine versus aprepitant for the prevention of chemotherapy-induced nausea and vomiting: a randomized phase III trial. J Support Oncol. 2011;9(5):188-195.

18. Tan L, Liu J, Liu X, et al. Clinical research of olanzapine for prevention of chemotherapy-induced nausea and vomiting. J Exp Clin Cancer Res. 2009;28:131.

19. Navari RM, Qin R, Ruddy KJ, et al. Olanzapine for the prevention of chemotherapy-induced nausea and vomiting. N Engl J Med. 2016;375(2): 134-142.

20. Roila F, Molassiotis A, Herrstedt J, et al. 2016 MASCC and ESMO guideline update for the prevention of chemotherapy- and radiotherapyinduced nausea and vomiting and of nausea and vomiting in advanced cancer patients. Ann Oncol. 2016;27(Suppl 5):v119-v133.

21. Hesketh PJ, Bohlke K, Lyman GH, et al. Antiemetics: American Society of Clinical Oncology focused guideline update. J Clin Oncol. 2016;34(4):381-386.

22. Duffy RA, Morgan C, Naylor R, et al. Rolapitant (SCH 619734): a potent, selective and orally active neurokinin NK1 receptor antagonist with centrally-mediated antiemetic effects in ferrets. Pharmacol Biochem Behav. 2012;102(1):95-100.

23. Poma A, Christensen J, Davis J, Kansra V, Martell R, Hedley M. Phase 1 positron emission tomography (PET) study of the receptor occupancy of rolapitant, a novel NK-1 receptor antagonist. J Clin Oncol. 2014;32(suppl):Abstract e20690.

24. Van Laere K, De Hoon J, Bormans G, et al. Equivalent dynamic human brain NK1-receptor occupancy following single-dose i.v. fosaprepitant vs. oral aprepitant as assessed by PET imaging. Clin Pharmacol Ther. 2012;92(2):243-250. 
25. Spinelli T, Calcagnile S, Giuliano C, et al. Netupitant PET imaging and ADME studies in humans. J Clin Pharmacol. 2014;54(1):97-108.

26. Varubi ${ }^{\circledR}$ (rolapitant) [package insert]. Waltham, MA: Tesaro; 2015.

27. Gan TJ, Gu J, Singla N, et al. Rolapitant for the prevention of postoperative nausea and vomiting: a prospective, double-blinded, placebocontrolled randomized trial. Anesth Analg. 2011;112(4):804-812.

28. Emend (fosaprepitant dimeglumine) for injection [package insert]. Whitehouse, NJ: Merck Sharp \& Dohme Corp.; 2016.

29. Emend (aprepitant) [package insert]. Whitehouse, NJ: Merck Sharp \& Dohme Corp.; 2015.

30. Akynzea $^{\circledR}$ (netupitant and palonosetron) [package insert]. Woodcliff Lake, NJ: Eisai Inc.; 2015.

31. Poma A, Christensen J, Pertikis H, Arora S, Hedley M. Rolapitant and its major metabolite do not affect the pharmacokinetics of midazolam, a sensitive cytochrome P450 3A4 substrate. Support Care Cancer. 2013;21:S154. Abstract 441

32. Wang X, Wang J, Kansra V. Population pharmacokinetics of rolapitant in patients with chemotherapy-induced nausea and vomiting. European Cancer Congress; Vienna, Austria; September 25-29, 2015. Poster 1588.

33. Hesketh PJ, Grunberg SM, Gralla RJ, et al. The oral neurokinin-1 antagonist aprepitant for the prevention of chemotherapy-induced nausea and vomiting: a multinational, randomized, double-blind, placebo-controlled trial in patients receiving high-dose cisplatin - the Aprepitant Protocol 052 Study Group. J Clin Oncol. 2003;21(22):4112-4119.

34. Poli-Bigelli S, Rodrigues-Pereira J, Carides AD, et al. Addition of the neurokinin 1 receptor antagonist aprepitant to standard antiemetic therapy improves control of chemotherapy-induced nausea and vomiting. Results from a randomized, double-blind, placebo-controlled trial in Latin America. Cancer. 2003;97(12):3090-3098.

35. Rapoport BL, Jordan K, Boice JA, et al. Aprepitant for the prevention of chemotherapy-induced nausea and vomiting associated with a broad range of moderately emetogenic chemotherapies and tumor types: a randomized, double-blind study. Support Care Cancer. 2010;18(4):423-431.

36. Nishimura J, Satoh T, Fukunaga M, et al. Combination antiemetic therapy with aprepitant/fosaprepitant in patients with colorectal cancer receiving oxaliplatin-based chemotherapy (SENRI trial): a multicentre, randomised, controlled phase 3 trial. Eur J Cancer. 2015; 51(10):1274-1282.

37. Grunberg S, Chua D, Maru A, et al. Single-dose fosaprepitant for the prevention of chemotherapy-induced nausea and vomiting associated with cisplatin therapy: randomized, double-blind study protocol-EASE. J Clin Oncol. 2011;29(11):1495-1501.

38. Weinstein C, Jordan K, Green SA, et al. Single-dose fosaprepitant for the prevention of chemotherapy-induced nausea and vomiting associated with moderately emetogenic chemotherapy: results of a randomized, double-blind phase III trial. Ann Oncol. 2016;27(1):172-178.

39. Hesketh PJ, Rossi G, Rizzi G, et al. Efficacy and safety of NEPA, an oral combination of netupitant and palonosetron, for prevention of chemotherapy-induced nausea and vomiting following highly emetogenic chemotherapy: a randomized dose-ranging pivotal study. Ann Oncol. 2014;25(7):1340-1346.

40. Aapro M, Rugo H, Rossi G, et al. A randomized phase III study evaluating the efficacy and safety of NEPA, a fixed-dose combination of netupitant and palonosetron, for prevention of chemotherapy-induced nausea and vomiting following moderately emetogenic chemotherapy. Ann Oncol. 2014;25(7):1328-1333.

41. Rapoport B, Chua D, Poma A, Arora S, Wang Y, Fein LE. Study of rolapitant, a novel, long-acting, NK-1 receptor antagonist, for the prevention of chemotherapy-induced nausea and vomiting (CINV) due to highly emetogenic chemotherapy (HEC). Support Care Cancer. 2015;23(11):3281-3288.

42. Rapoport BL, Chasen MR, Gridelli C, et al. Safety and efficacy of rolapitant for prevention of chemotherapy-induced nausea and vomiting after administration of cisplatin-based highly emetogenic chemotherapy in patients with cancer: two randomised, active-controlled, double-blind, phase 3 trials. Lancet Oncol. 2015;16(9):1079-1089.
43. Schwartzberg LS, Modiano MR, Rapoport BL, et al. Safety and efficacy of rolapitant for prevention of chemotherapy-induced nausea and vomiting after administration of moderately emetogenic chemotherapy or anthracycline and cyclophosphamide regimens in patients with cancer: a randomised, active-controlled, double-blind, phase 3 trial. Lancet Oncol. 2015;16(9):1071-1078.

44. Hesketh PJ, Schnadig ID, Schwartzberg LS, et al. Efficacy of the neurokinin-1 receptor antagonist rolapitant in preventing nausea and vomiting in patients receiving carboplatin-based chemotherapy. Cancer. 2016;122(15):2418-2425.

45. Navari RM, Aapro M. Antiemetic prophylaxis for chemotherapyinduced nausea and vomiting. NEngl J Med.2016;374(14):1356-1367.

46. Barbour S, Wang X, Poma A, Arora S, Aapro M, Herrstedt J. Low risk of drug interactions with rolapitant is coadministered with CYP2S6 or BCRP substrates: integrated safety results. European Cancer Congress; Vienna, Austria; September 25-29, 2015. Poster 1529.

47. Rapoport B, Schwartzberg L, Chasen M, et al. Efficacy and safety of rolapitant for prevention of chemotherapy-induced nausea and vomiting over multiple cycles of moderately or highly emetogenic chemotherapy. Eur J Cancer. 2016;57:23-30.

48. Palli SR, Grabner M, Quimbo RA, Rugo HS. The impact of 5-hydroxytryptamine-receptor antagonists on chemotherapy treatment adherence, treatment delay, and nausea and vomiting. Cancer Manag Res. 2015;7:175-188.

49. Burke TA, Wisniewski T, Ernst FR. Resource utilization and costs associated with chemotherapy-induced nausea and vomiting (CINV) following highly or moderately emetogenic chemotherapy administered in the US outpatient hospital setting. Support Care Cancer. 2011;19(1):131-140.

50. Gomez DR, Liao KP, Giordano S, Nguyen H, Smith BD, Elting LS. Adherence to national guidelines for antiemesis prophylaxis in patients undergoing chemotherapy for lung cancer: a population-based study. Cancer. 2013;119(7):1428-1436.

51. EscobarY, Cajaraville G, Virizuela JA, et al. Incidence of chemotherapyinduced nausea and vomiting with moderately emetogenic chemotherapy: ADVICE (Actual Data of Vomiting Incidence by Chemotherapy Evaluation) study. Support Care Cancer. 2015;23(9):2833-2840.

52. Molassiotis A, Saunders MP, Valle J, et al. A prospective observational study of chemotherapy-related nausea and vomiting in routine practice in a UK cancer centre. Support Care Cancer. 2008;16(2):201-208.

53. Grassi L, Berardi MA, Ruffilli F, et al. Role of psychosocial variables on chemotherapy-induced nausea and vomiting and health-related quality of life among cancer patients: a European study. Psychother Psychosom. 2015;84(6):339-347.

54. Lindley CM, Hirsch JD, O’Neill CV, Transau MC, Gilbert CS, Osterhaus JT. Quality of life consequences of chemotherapy-induced emesis. Qual Life Res. 1992;1(5):331-340.

55. Martin AR, Pearson JD, Cai B, Elmer M, Horgan K, Lindley C. Assessing the impact of chemotherapy-induced nausea and vomiting on patients' daily lives: a modified version of the Functional Living Index-Emesis (FLIE) with 5-day recall. Support Care Cancer. 2003; 11(8):522-527.

56. Chasen M, Urban L, Schnadig I, et al. Impact of rolapitant on quality of life $(\mathrm{QoL})$ in patients (pts) receiving highly emetogenic chemotherapy (HEC) and moderately emetogenic chemotherapy (MEC). Poster presented at: 2015 ASCO Annual Meeting; May 29 - June 2, 2015; Chicago, IL. Abstract 9615.

57. Chasen M, Urban L, Schnadig I, et al. Rolapitant improves quality of life of patients receiving highly or moderately emetogenic chemotherapy. Support Care Cancer. 2017;25(1):85-92.

58. Basch E, Prestrud AA, Hesketh PJ, et al. Antiemetics: American Society of Clinical Oncology clinical practice guideline update. J Clin Oncol. 2011;29(31):4189-4198.

59. Aapro M, Karthaus M, Schwartzberg L, et al. Phase 3 study of NEPA, a fixed-dose combination of netupitant and palonosetron, for prevention of chemotherapy-induced nausea and vomiting during repeated moderately emetogenic chemotherapy (MEC) cycles. J Clin Oncol. 2014;32(supp1):Abstract 9502. 


\section{Publish your work in this journal}

Cancer Management and Research is an international, peer-reviewed open access journal focusing on cancer research and the optimal use of preventative and integrated treatment interventions to achieve improved outcomes, enhanced survival and quality of life for the cancer patient. The manuscript management system is completely online and includes a very quick and fair peer-review system, which is all easy to use. Visit http://www.dovepress.com/testimonials.php to read real quotes from published authors.

Submit your manuscript here: https://www.dovepress.com/cancer-management-and-research-journal 